\title{
ВИВЧЕННЯ РЕЖИМІВ ЗГУЩЕННЯ ПРИ ОДЕРЖАННІ ГУСТОГО ЕКСТРАКТУ ЧЕБРЕЦЮ ПОВЗУЧОГО
}

\begin{abstract}
Вступ. Одним із пріоритетних напрямків сучасної фрармації є створення нових лікарських засобів рослинного походження. Лікарська рослинна сировина і рослинні препарати при правильному дозуванні практично не токсичні, не шкідливі, відносно доступні та ефективні. Актуальною лікарською рослинною сировиною, що характеризується високим складом і вмістом біологічно активних речовин, $є$ трава чебрецю повзучого. Чебрець повзучий (Thymus serpyllum) родини ясноткові (Lamiaceae) розповсюджений на території України в дикому вигляді та широко культивується. Як відомо, препарати на основі досліджуваної сировини призначають при захворюваннях дихальних шляхів - бронхітах, запаленні легень, кашлюку тощо. Фармацевтична розробка передбачає отримання густого екстракту чебрецю повзучого.

Мета дослідження - підібрати режими згущення та визначити оптимальні умови при розробці технології отримання густого екстракту чебрецю повзучого.

Методи дослідження. Під час дослідження було використано таке обладнання: насос глибокого вакууму VT6 з максимальним розрідженням до 0,85 кгс/см² із вакуумметром ОБВ 1-100 з діапазоном вимірювання від о до -1 кес/см²; лабораторний роторний випарювач LABOROTA 4001, валкову дробарку, сита, вагу КП4, екстрактор, нержавіючу стальну чашу, термометр.

Результати й обговорення. У результаті проведеного експерименту вибрано оптимальну температуру упарювання - 65-70 ${ }^{\circ} \mathrm{C}$, визначено час упарювання - 4-4,5 год і одержано густий екстракт чебрецю повзучого, який являє собою густу в'язку масу, що не виливається з тари, а розтягується в нитки і знову зливається в суцільну масу зі специорічним запахом та задовільними фрармакотехнологічними показниками. Враховуючи те, що густий екстракт - це складна фрізико-хімічна система, яка складається $з$ френольних сполук, що є термолабільними, підвищення температури понад $70{ }^{\circ} \mathrm{C}$ призводило до зниження вмісту фрлавоноїдів, які обрано маркерами якості досліджуваного екстракту.

Висновок. Вивчено режими згущення при отриманні густого екстракту чебрецю повзучого, вибрано оптимальні умови одержання досліджуваного екстракту, які полягають у випаровуванні під вакуумом при температурі 60-70 ㄷ і залишковому вакуумі 0,8 кгс/см². Як результат отримано густий екстракт чебрецю повзучого із задовільними показниками якості, що дозволить у майбутньому розробити лікарський засіб належної якості.
\end{abstract}

КЛЮЧОВІ СЛОВА: лікарська рослинна сировина; чебрець повзучий; екстракт; маркери якості; технологія.

ВСТУП. Дослідження біологічно активних речовин рослинної сировини та розробка на їх основі вітчизняних лікарських препаратів $€$ актуальним завданням фрармації на сьогодні [1]. Згідно з даними літератури [1-3], трава чебрецю повзучого містить складний комплекс біологічно активних сполук моно- і сесквітерпенового ряду, прості френольні сполуки, фрлавоноїди, гідроксикоричні кислоти, які разом зумовлюють різну срармакологічну активність сировини та субстанцій, отриманих на її основі [3]. Фармацевтична розробка передбачає отримання густого екстрак(c) Н. О. Зарівна, 2019 . ту чебрецю повзучого, тому метою дослідження було підібрати режими згущення та визначити оптимальні умови при розробці технології його одержання.

МЕТОДИ ДОСЛІДЖЕННЯ. ПіД час дослідження використовували рідкий екстракт чебрецю повзучого, який одержали за технологією, описаною в патенті України на корисну модель № 73543 [4], і таке обладнання: насос глибокого вакууму VT6 з максимальним розрідженням до

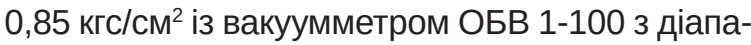

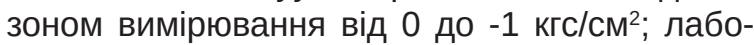


раторний роторний випарювач LABOROTA4001, валкову дробарку, сита, вагу КП4, екстрактор, нержавіючу стальну чашу, термометр.

У ході виконання експерименту було відібрано по 500 мл екстракту чебрецю повзучого. Упарювання проводили до об'єму 100 мл, фріксуючи його час за таких умов:

1) значення температури - $60^{\circ} \mathrm{C}$, вакууму $0,6 \mathrm{kгc} / \mathrm{cm}^{2}$;

2) значення температури - $60^{\circ} \mathrm{C}$, вакууму -

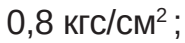

3) значення температури - $80^{\circ} \mathrm{C}$, вакууму $0,6 \mathrm{Krc} / \mathrm{cm}^{2}$;

4) значення температури - $80^{\circ} \mathrm{C}$, вакууму $0,8 \mathrm{\kappa} г \mathrm{c} / \mathrm{cm}^{2}$.

РЕЗУЛЬТАТИ Й ОБГОВОРЕННЯ. ТЕХНОЛОгічний процес виробництва густого екстракту чебрецю повзучого складається з таких стадій:

ДР.1. Санітарна підготовка виробництва.

ДР.2. Підготовка сировини.

ТПЗ. Отримання рідкого екстракту з трави чебрецю повзучого.

ТП4. Отримання густого екстракту чебрецю повзучого.

Санітарна підготовка виробництва включає такі операції:

ДР1.1. Приготування дезінфекційних розчинів.

ДР1.2. Підготовка вентиляційного повітря.

ДР1.3. Підготовка виробничих приміщень.

ДР1.4. Підготовка обладнання та інвентарю.

ДР1.5. Підготовка технологічного одягу.

ДР1.6. Підготовка робочого персоналу.

Технологічну стадію ДР2 (підготовка сировини) здійснюють у приміщеннях складування сировини. Сировину і допоміжні матеріали зберігають на складах на піддонах або стелажах за найменуваннями згідно з вибухонебезпечними і токсикологічними властивостями відповідно до вимог Правил пожежної безпеки для підприємств з виробництва лікарських засобів (НАПБ В.01.051-99/191).

Вхідний контроль сировини і матеріалів проводить ВКЯ згідно з КД 64У-2-95 “Вхідний контроль сировини і матеріалів для виробництва продукції медичної та мікробіологічної промисловості". Відбирають проби відповідно до НРН. QM.QC.U5.Sam.01.In "Порядок відбору проб вихідної сировини" на складі сировини в спеціально відведеному приміщенні класу D, обладнаному припливно-витяжною вентиляцією.

Технологічну стадію ДР.2.1 (подрібнення сировини (трави) чебрецю повзучого) здійснюють у приміщенні подрібнення сировини на валковій дробарці типу ПД-630 поз. РМ73 відповідно до НPH.M.EP.SOE.Chem.U1.03.In.
За допомогою сит для ручного просіву перевіряють розмір подрібнених частинок, який повинен становити в середньому 1-2 мм. Роботу на подрібнювальному обладнанні проводять при постійно діючій припливно-витяжній вентиляції та місцевому відсмоктуванні, які забезпечують вміст рослинного пилу в повітрі в концентрації, не вищій від граничнодопустимої. У бункер завантажують траву чебрецю повзучого, попередньо зважену на вазі поз. КП4, в кількості 154,0 кг (К2.1.1), періодично перевіряють розмір розчавленої рослинної сировини (К2.1.2). Після цього подрібнену траву чебрецю повзучого (ДР.2.1) збирають у чисті поліетиленові мішки, маркують етикеткою “Проміжна продукція" відповідно до НPH.M.EP.SOE.Chem.Com.38.In, зважують на вазі поз. КП4 і передають у приміщення екстракції.

Технологічна стадія ТПЗ (отримання рідкого екстракту з трави чебрецю повзучого) включає такі операції:

ТП3.1. Приготування 60 \% водно-спиртової суміші.

ТП3.2. Приготування 30 \% водно-спиртової суміші.

ТП3.3. Екстракція трави чебрецю повзучого.

Екстракцію проводять 60 і 30 \% водно-спиртовими сумішами та водою гарячою $\left(95^{\circ} \mathrm{C}\right)$. У підготовлений апарат поз. 378 самопливом із мірника поз. М75 подають спирт етиловий 96,5 \% у відповідному об'ємному співвідношенні. Зі збірника поз. 379 (на заповнення) перетискають за допомогою інертного газу в мірник поз. М75 слабкий екстракт, відсмоктаний із трави чебрецю повзучого (250,0 л), і відігнаний (150,61 л) з екстрактора спирт етиловий із шроту. Зі збірника поз. 383 (на витіснення) перетискають за допомогою інертного газу в мірник поз. М75 спирт етиловий, отриманий після упарювання екстракту (361,56 л), і самопливом із мірника поз. М75 подають в апарат поз. 378 (К3.1.1).

3 відділення водопідготовки за допомогою вакууму подають очищену воду поз. М9 в апарат поз. Р76 (К3.1.2) та вмикають мішалку для перемішування впродовж 10-15 хв (К3.1.3) спирту. Після цього відбирають проби водно-спиртових сумішей відповідно до HPH.M.EP.SOE.Chem. Com.14.In та визначають концентрацію спирту етилового в них (К3.1.4) згідно з HPH.M.EP.SOE. Chem.U1.76.In.

Приготовлений екстрагент перетискають за допомогою інертного газу в мірник поз. М75 і 3 нього при необхідності передають на наступну операцію ТП3.2. Перед завантаженням мірник поз. М75 продувають інертним газом (тиск азо-

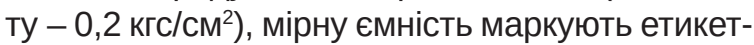


кою "Проміжна продукція" відповідно до HPH.M.EP.SOE.Chem.Com.38.In.

Процес екстрагування трави чебрецю повзучого (ТПЗ.3. Екстракція трави чебрецю повзучого) проводять методом реперколяції в батареї з 4-х екстракторів поз. P11 (1, 2, 3, 4), які експлуатують відповідно до HPH.M.EP.SOE. Chem.U1.15.In.

У підготовлений екстрактор поз. Р11(1) через верхній люк завантажують зважену на вазі поз. КП4 подрібнену траву чебрецю повзучого в кількості 150 кг (К3.2.1), а зверху на неї вкладають нержавіючий стальний сітчастий круг. Після завантаження екстрактор щільно закривають кришкою. 3 мірника поз. М75 через нижній зливний кран екстрактора поз. Р11(1) самопливом подають 60 \% водно-спиртову суміш у кількості 500 л до утворення над сировиною чебрецю повзучого дзеркала розчинника (К3.2.2). Наповнення і витіснення екстракту проводять зі швидкістю 40 л/год (К3.2.3). Настоюють 12 год (К3.2.4). Одночасно з цим готують до роботи наступний екстрактор з аналогічним завантаженням рослинної сировини. Після закінчення часу настоювання до верхнього зливного патрубка екстрактора поз. Р11(1) підключають нижній зливний патрубок другого екстрактора поз. Р11(2), завантаженого рослинною сировиною. 3 мірника поз. M75 в екстрактор поз. P11(1) самопливом через нижній зливний кран подають 500 л 30 \% водноспиртової суміші, витісняючи первинний екстракт з екстрактора поз. Р11(1) в екстрактор поз. P11(2). Заповнення проводять до появи первинного екстракту у верхньому зливному патрубку екстрактора поз. Р11(2). Обидва заповнених екстрактори залишають для настоювання впродовж 12 год. Паралельно готують до роботи наступний третій екстрактор $з$ аналогічним завантаженням рослинної сировини. Після настоювання в екстракторах поз. P11(1) і поз. P11(2) 3 мірника поз. М75 в екстрактор поз. P11(1) знову подають 500 л 30 \% водно-спиртової суміші, що витісняє 3 нього екстракт в екстрактор поз. P11(2), з якого через патронний фрільтр поз. Ф12, заправлений марлею, витісняється 500 л екстракту в збірник поз. 378 (КЗ.2.5). Збірник поз. 378 обладнаний мірним склом, манометром поз. КП7.

Після вивантаження екстракту до батареї екстракторів поз. P11(1) і поз. Р11(2) підключають екстрактор поз. P11(3) із завантаженою рослинною сировиною і заповнюють його через 2 попередні екстрактори, подаючи 500 л 30 \% водно-спиртової суміші самопливом із мірника поз. M75 в екстрактор поз. P11(1). Після закінчення наповнення проводять настоювання в 3-х екстракторах упродовж 12 год. Після цього з екстрактора поз. Р11(3) витісняється в збірник поз. 378 через патронний фрільтр 500 л екстракту методом подачі (3 год) води гарячої $\left(95^{\circ} \mathrm{C}\right)$ в кількості 500 л в екстрактор поз. Р11(1). До батареї екстракторів поз. P11(1), поз. P11(2) і поз. P11(3) підключають екстрактор поз. Р11(4) із завантаженою сировиною та заповнюють його через 3 попередні екстрактори, подаючи 500 л свіжої суміші самопливом із мірника поз. М75 в екстрактор поз. P11(1). Після закінчення наповнення проводять настоювання в екстракторах поз. Р11(2), поз. Р11(3) і поз. Р11(4) впродовж 12 год, а екстрактор поз. Р11(1) відключають (так закінчується пусковий режим - розгортання батареї, робочий період починається з другого обороту 1-го перколятора).

На екстракторі поз. P11(1) закривають усі вентилі, крім вентиля на лінії відсмоктування. На збірнику поз. 379, обладнаному мановакуумметром поз. КП16, вмикають вакуум і проводять відсмоктування слабкого екстракту з екстрактора поз. Р11(1) до кількості 250 л (К3.2.6) 3 наступною подачею його в мірник поз. М75 з метою використання на стадії екстракції після відповідного коректування. Відсмоктування здійснюють при вакуумі 0,6-0,7 кгс/см² протягом 1,5-2 год (К3.2.7). Слабкий екстракт аналізують на вміст спирту за методикою КЗ.2.10 (для спирту). Після відсмоктування екстрагенту закривають вентиль на лінії відсмоктування, подають воду на теплообмінник поз. Т20, гостру пару в екстрактор поз. P11(1) і пару в оболонку екстрактора.

Спиртову суміш відганяють у збірник поз. 379 впродовж 8-8,5 год глухою і гострою парою (К3.2.9) до повного зникнення спирту з трави чебрецю повзучого. Після закінчення відгону припиняють подачу гострої пари, зливають воду з екстрактора, яка там залишилась, і вивантажують відпрацьований шрот відповідно до HPH.M.EP.SOE.Chem.Com.02.In. 3 отриманого рідкого екстракту відбирають пробу згідно 3 HPH.M.EP.SOE.Chem.Com.14.In. для проведення аналізу за методикою (К3.2.10). При регенерації відпрацьованого шроту одержують близько 150,61 л водно-спиртової суміші (К3.2.11), яку аналізують на вміст спирту згідно з НPH.M.EP. SOE.Chem.U1.76.In. (К3.2.12). Водно-спиртову суміш подають у мірник поз. М75 з метою використання її на стадії екстракції після відповідного коректування.

Технологічна стадія ТП4 (отримання густого екстракту чебрецю повзучого) складається 3 таких операцій:

ТП4.1. Відстоювання водно-спиртового екстракту чебрецю повзучого.

ТП4.2. Упарювання екстракту.

Відстоювання водно-спиртового екстракту чебрецю повзучого (ТП4.1) проводять у нержа- 
віючій стальній чаші поз. Р80, обладнаній оболонкою для охолодження. Водно-спиртовий екстракт у кількості 500 л самопливом подають із збірника екстракту поз. 378 в чашу поз. Р80, розсіл подають в оболонку чаші й відстоюють екстракт при температурі $3-5^{\circ} \mathrm{C}$ не менше однієї доби для отримання прозорої рідини (К4.1.1). Після відстоювання водно-спиртовий екстракт чебрецю повзучого передають вакуумом у вакуум-випарний апарат поз. Р81.

Упарювання екстракту (ТП4.2) проводять у вакуум-випарному апараті поз. Р81, обладнаному паровою оболонкою, термометром поз. КП37, мановакуумметром поз. КП16, теплообмінником поз. Т82 і збірником конденсату поз. 383. Подають пару в оболонку апарата, відгін проводять при температурі від 60 до $80{ }^{\circ} \mathrm{C}$ i вакуумі $(0,7 \pm 0,1) \mathrm{krc/ \textrm {cm } ^ { 2 }}(\mathrm{K} 4.2 \cdot 1)$. Температуру контролюють кожні 15 хв (К4.2.2). Процес продовжують до того часу, поки кількість конденсату не становитиме близько 361,56 л (К4.2.3) або поки не з'являться сліди спирту (спостерігатимуть голубувате забарвлення конденсату). Отриманий відігнаний спирт аналізують на вміст спирту етилового згідно з HPH.M.EP.SOE.Chem. U1.76.In. (K4.2.4). Його подають у мірник поз. M75 і після відповідного коректування використовують на екстракціях наступних завантажень. Процес випарювання продовжують при температурі 80-100 ${ }^{\circ} \mathrm{C}$ (К4.2.5). Отриманий густий екстракт чебрецю повзучого аналізують за методикою (К4.2.6).

У разі отримання негативного результату щодо вмісту вологи всю серію густого екстракту чебрецю повзучого піддають додатковому випарюванню, після чого ії̈ повторно контролюють на втрату в масі під час висушування. При одержанні позитивного результату аналізу продукт дають на упаковку. Отриманий конденсат води після доупарювання екстракту можна використовувати для одержання екстрагенту.
Густий екстракт чебрецю повзучого з вакуум-випарного апарата поз. Р81 переносять у чисту суху поліетиленову бочку. Контролер ВКЯ підприємства відбирає пробу готової продукції для аналізу на відповідність вимогам МКя № UA/6809/01/01 (K4.2.7).

Як свідчать результати дослідження, наведені в таблиці 1, суттєве значення для одержання густого екстракту має температура упарювання, а саме приблизно на 50 \% швидше упарюється екстракт при $80{ }^{\circ} \mathrm{C}$ порівняно $360{ }^{\circ} \mathrm{C}$ упарювання. При розрідженні вакууму 0,8 кгс/см ${ }^{2}$ приріст становить близько 15-20 \% порівняно 3 вакуумом 0,6 кгс/см².

Оптимальною температурою упарювання, як видно з результатів експерименту (табл. 2), $\epsilon$ температура $60-70^{\circ} \mathrm{C}$, при цьому час упарювання становить 4-4,5 год. Через те, що екстракт являє собою складну фрізико-хімічну систему, яка складається з багатьох індивідуальних речовин, а саме фенольних сполук (апігенін і лютеолін та їх глікозиди, кофейна, хлорогенова і розмаринова кислоти тощо) [5], що є термолабільними сполуками, підвищення температури понад $70^{\circ} \mathrm{C} є$ ризикованим з огляду на зниження кількісного вмісту фрлавоноїдів, які ми попередньо обрали маркерами якості одержаного екстракту [5-7].

У результаті проведеного дослідження отримали готовий продукт - густий екстракт трави чебрецю повзучого, який являє собою густу в'язку масу, що не виливається з тари, а розтягується в нитки і знову зливається в суцільну масу зі специсрічним запахом та задовільними параметрами якості [8].

Оскільки при аналізі трави чебрецю повзучого $з$ метою стандартизації цієї сировини як показник якості, серед інших, ми обрали склад фрлавоноїдів і гідроксикоричних кислот та кількісний вміст фрлавоноїдів [5-7], то доречним $€$ вивчення якісного та кількісного складу цих біо-

Таблиця 1 - Режими згущення рідкого екстракту чебрецю повзучого

\begin{tabular}{|l|c|c|c|c|}
\hline \multirow{2}{*}{ Режим } & \multicolumn{4}{|c|}{ Температура, ${ }^{\circ} \mathrm{C}$} \\
\cline { 2 - 5 } & \multicolumn{2}{|c|}{60} & \multicolumn{3}{c|}{80} \\
\hline Вакуум, кгс/см ${ }^{2}$ & 0,6 & 0,8 & 0,6 & 0,8 \\
\hline Час упарювання, хв (3 500 мл до 100 мл ) & 95 & 80 & 65 & 55 \\
\hline
\end{tabular}

Таблиця 2 - Залежність тривалості упарювання від його температури

\begin{tabular}{|c|c|c|c|}
\hline $\begin{array}{c}\text { 3начення вакууму, } \\
\text { кгс/см² }\end{array}$ & $\begin{array}{c}\text { Температура } \\
\text { упарювання, }{ }^{\circ} \mathrm{C}\end{array}$ & Тривалість упарювання, год & Вміст фрлавоноїдів, г \\
\hline 0,8 & 30 & 9 & $2,73 \pm 0,04$ \\
\hline 0,8 & 40 & 7 & $2,72 \pm 0,03$ \\
\hline 0,8 & 50 & 5,5 & $2,73 \pm 0,04$ \\
\hline 0,8 & 60 & 4,5 & $2,72 \pm 0,03$ \\
\hline 0,8 & 70 & 4 & $2,72 \pm 0,02$ \\
\hline 0,8 & 80 & 4 & $2,70 \pm 0,02$ \\
\hline
\end{tabular}


логічно активних речовин і в одержаному екстракті, що стане наступним етапом досліджень.

ВИСНОВКИ. 1. Досліджено режими згущення при отриманні густого екстракту чебрецю повзучого.

\section{СПИСОК ЛІТЕРАТУРИ}

1. Матвеева В. Фитомедицина - путь к здоровью, фритониринг - будущее фитотерапии / В. Матвеева // Еженедельник АПТЕКА. - 2002. - № 41 (362). - С. 4-5.

2. Грущенко Л. Чебрецевий рай. Високі технології Лубенської дослідної станції лікарських рослин Інституту агроекології УААН / Л. Грущенко, В. Рак // Фармацевт - практик : наук.-попул. та станово-побутовий журн. - 2010. - № 9. - С. 26-28.

3. Thyme: The genus Thymus. London, New York: Taylor, Fransis. - 2002. - 330 p.

4. Пат. 73543 Україна, МПК ${ }^{51}$ C 11 В 1/10, А 61 K 9/08, А 61 К 35/00. Спосіб отримання рідкого екстракту чебрецю повзучого / Н. О. Зарівна, Л. В. Вронська, Т. А. Грошовий ; заявник і патентовласник Терноп. держ. мед. ун-т імені І. Я. Горбачевського. - Заявл. 26.03.12 ; опубл. 25.09.12, Бюл. № 18.

5. Зарівна Н. О. Стандартизація рідкого екстракту чебрецю повзучого / Н. О. Зарівна, Л. В. Врон-
2. Вибрано оптимальні умови одержання досліджуваного екстракту, які полягають у випаровуванні під вакуумом при температурі 60-

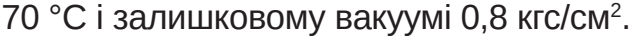

ська // Укр. біофрармац. журн. - 2012. - № 5-6. C. 108-112.

6. Зарівна Н. О. До питання стандартизації трави чебрецю / Н. О. Зарівна, Л. В. Вронська // Актуальні питання створення нових лікарських засобів : матеріали Всеукр. наук.-практ. конср. студентів та молодих вчених, 21 квіт. 2011 р. - Харків, 2011. - С. 65.

7. Зарівна Н. О. До питання стандартизації трави чебрецю повзучого за вмістом фрлавоноїдів / Н. О. Зарівна, Л. В. Вронська // Управління, економіка та забезпечення якості в фрармації. - 2012. - № 5 (25). С. 21-27.

8. Державна фрармакопея України : в 3 т. / Державне підприємство "Український науково-експертний фрармакопейний центр якості лікарських засобів". 2-ге вид. - Харків : Державне підприємство "Український науково-експертний фрармакопейний центр якості лікарських засобів", 2015. - 1. - 1128 с.

\section{REFERENCES}

1. Matveyeva, V. (2002). Fitomeditsyna - put k zdorovyu, fitonirynh - budushche fitoterapii [Phytomedicine - the way to health, phytoning - the future of herbal medicine]. Ezhenedelnyk APTEKA - Weekly PHARMACY, 41, (362), 4-5 [in Russian].

2. Hrushchenko, L., \& Rak, V. (2010). Chebretsevyi rai. Vysoki tekhnolohii Lubenskoi doslidnoi stantsii likarskykh roslyn Instytutu ahroekolohii UAAN [Thyme paradise. High technologies of Lubensk Medicinal Plants Research Station of the Institute of Agroecology of the UAAS]. Farmatsevt - praktyk: nauk.-popul. ta stanovopobutovyi zhurn. - Pharmacist - Practitioner: Popular Science Journal, 9, 26-28 [in Ukrainian].

3. (2002). Thyme: The genus Thymus. London, New York: Taylor, Fransis.

4. (2012). Zarivna, N.O., Vronska, L.V., Hroshovyi, T.A. Pat. Ukrainy, Sposib otrymannia ridkoho ekstraktu chebretsiu povzuchoho [Patent of Ukraine: The method of obtaining liquid creeping thyme extract]. No. 73543 MPK51 S 11 V 1/10, A 61 K 9/08, A 61 K 35/00; Bull. No.18 [in Ukrainian].

5. Zarivna, N.O., \& Vronska, L.V. (2012). Standartyzatsiia ridkoho ekstraktu chebretsiu povzuchoho [Stan-

dardization of liquid creeping thyme extract]. Ukrainskyi biofarmatsevtychnyi zhurnal - Ukrainian Biopharmaceutical Journal, 5-6, 108-112 [in Ukrainian].

6. Zarivna, N.O., Vronska, L.V. (2011). Do pytannia standartyzatsii travy chebretsiu [To the standardization of thyme herbs]. Materialy vseukrainskoi nauk.-prakt.konf. studentiv ta molodykh vchenykh "Aktualni pytannia stvorennia novykh likarskykh zasobiv": materialy konferentsii - Materials of All-Ukrainian Practical Conference of Students and Young Scientists. Kharkiv. (p. 65) [in Ukrainian].

7. Zarivna, N.O., \& Vronska, L.V. (2012). Do pytannia standartyzatsii travy chebretsiu povzuchoho za vmistom flavonoidiv [On the standardization of creeping thyme by the content of flavonoids]. Upravlinnia, ekonomika ta zabezpechennia yakosti $v$ farmatsii - Management, Economics and Quality Assurance in Pharmacy, 5 (25), 21-27 [in Ukrainian].

8. (2015). Derzhavna Farmakopeia Ukrainy: $v 3 t$. [State Pharmacopoeia of Ukraine:in 3 vol.]. State Enterprise "Ukrainian Scientific Pharmacopoeia Center for the Quality Medicines " [in Ukrainian]. 
Н. О. Заривна

\title{
ИЗУЧЕНИЕ РЕЖИМОВ СГУЩЕНИЯ ПРИ ПОЛУЧЕНИИ ГУСТОГО ЭКСТРАКТА ТИМЬЯНА ПОЛЗУЧЕГО
}

\begin{abstract}
Резюме
Вступление. Одним из приоритетных направлений современной фрармации является создание новых лекарственных средств растительного происхождения. Лекарственное растительное сырье и растительные препараты при правильной дозировке практически не токсичны, безвредны, относительно доступны и эфрфективны. Актуальным лекарственным растительным сырьем, которое характеризуется высоким составом и содержанием биологически активных веществ, является трава тимьяна ползучего. Тимьян ползучий (Thymus serpyllum) семейства яснотковые (Lamiaceae) распространен на территории Украины в диком виде и широко культивируется. Как известно, препараты на основе исследуемого сырья назначают при заболеваниях дыхательных путей - бронхитах, воспалении легких, коклюше и др. Фармацевтическая разработка предполагает получение густого экстракта тимьяна ползучего.
\end{abstract}

Цель исследования - подобрать режимы сгущения и определить оптимальные условия при разработке технологии получения густого экстракта тимьяна ползучего.

Методы исследования. Во время исследования было использовано такое оборудование: насос глубокого вакуума VT6 с максимальным разжежением до 0,85 кгс/см² с вакуумметром ОБВ 1-100 с диапазоном измерения от 0 до -1 кгс/см²; лабораторный роторный испаритель LABOROTA 4001, валковую дробилку, сита, весы КП4, экстрактор, нержавеющую стальную чашу, термометр.

Результаты и обсуждение. В результате проведенного эксперимента выбрано оптимальную температуру упаривания - 65-70 C, определено время упаривания - 4-4,5 ч и получено густой экстракт тимьяна ползучего, который представляет собой густую вязкую массу, которая не выливается из тары, а растягивается в нити и снова сливается в сплошную массу со специфрическим запахом и удовлетворительными фрармакотехнологическими показателями. Учитывая то, что густой экстракт - это сложная ффизико-химическая система, состоящая из френольных соединений, которые являются термолабильными, повышение температуры более $70{ }^{\circ} \mathrm{C}$ приводило к снижению содержания фрлавоноидов, которые выбраны маркерами качества исследуемого экстракта.

Выводы. Изучено режимы сгущения при получении густого экстракта тимьяна ползучего, выбрано оптимальные условия получения исследуемого экстракта, которые заключаются в испарении под вакуумом при температуре $60-70{ }^{\circ} \mathrm{C}$ и остаточном вакууме 0,8 кгс/см². Как результат получен густой экстракт тимьяна ползучего с удовлетворительными показателями качества, что позволит в будущем разработать лекарственное средство надлежащего качества.

КЛЮЧЕВЫЕ СЛОВА: лекарственное растительное сырье; тимьян ползучий; экстракт; маркеры качества; технология.

N. O. Zarivna

I. HORBACHEVSKY TERNOPIL NATIONAL MEDICAL UNIVERSITY

\section{STUDY CONCENTRATION MODES IN OBTAINING THICK EXTRACT OF THYME CREEPING}

\section{Summary}

Introduction. One of the priority areas of modern pharmacy is the creation of new herbal medicines. Medicinal herbs and herbal remedies, at the right dosage, are virtually non-toxic, harmless, relatively affordable and effective. Thyme creeping (Thymus serpyllum), Lamiaceae family is naturally distributed in the wild and widely cultivated in Ukraine. It is known that drugs based on the investigated raw material are prescribed for diseases of the respiratory tract - bronchitis, pneumonia, whooping cough and the like. Topical medicinal plant raw material, characterized by the diverse composition and content of biologically active substances is the herb thyme creeping. This development involves obtaining a thick extract.

The aim of the study - to select thickening modes and determine the optimal conditions for the development of creeping thyme technology to obtain a thick creeping thyme extract. 
Research Methods. During the study, the following equipment was used: VT6 deep vacuum pump with a maximum dilution of up to $0.85 \mathrm{kgf} / \mathrm{cm}^{2}$ with an OBV 1-100 vacuum gauge with a measuring range from 0 to $1 \mathrm{kgf/}$ cm2; laboratory rotary evaporator LABOROTA 4001, roller crusher, sieves, balance KP4, extractor, stainless steel bowl, thermometer.

Results and Discussion. As a result of the experiment, the optimum evaporation temperature of $65-70{ }^{\circ} \mathrm{C}$ has been selected, the evaporation time was determined - 4-4.5 h, and a thick extract has been obtained, which is a thick, viscous mass that does not flow out of the container but is stretched in threads and again merges into a solid mass with a specific odor with satisfactory pharmacological characteristics. Given that thick extract of thyme creeping is a complex physicochemical system consisting of phenolic compounds that are thermolabile, raising the temperature above $70^{\circ} \mathrm{C}$ leads to a decrease in the flavonoids content selected by the quality markers of the test extract.

Conclusions. The modes of condensation upon obtaining a thick creeping thyme extract have been investigated, and the optimal conditions for obtaining the test extract have been obtained, which consisted of evaporation under vacuum at a temperature of $60-70{ }^{\circ} \mathrm{C}$ and a residual vacuum of $0.8 \mathrm{kgf} / \mathrm{cm}^{2}$. As a result, a thick creeping thyme extract with satisfactory quality indicators is obtained, which will allow the development of a good quality medicinal product in the future.

KEY WORDS: medicinal herbs; creeping thyme; extract; quality markers; technology.

Отримано 11.10 .19

Адреса для листування: Н. О. Зарівна, Тернопільський національний медичний університет імені І. Я. Горбачевського МОз України, майдан Волі, 1, Тернопіль, 46001, Україна, e-mail: zarivna@tdmu.edu.ua. 